УДК $811.511 .131 ’ 373.21$

Л. Е. Кириллова

ГОДОНИМИЧЕСКАЯ ЛЕКСИКА В УДМУРТСКОМ ЯЗЫКЕ (НА МАТЕРИАЛЕ ТОПОНИМИИ)

В статье на основе изучения большого корпуса годонимов рассматриваются географические термины для обозначения улиц и переулков в удмуртском языке. При исследовании микротопонимов, собранных автором и другими топонимистами на территории Удмуртии и за ее пределами, в местах проживания удмуртов, автору удалось выявить значительное количество слов, выражающих данные понятия.

Для выражения понятия 'улица' в удмуртском языке используются слова ульча и урам, что подтверждается и данными удмуртской топонимики. Особое внимание уделяется описанию апеллятивов с семантикой 'переулок', зафиксированных в микротопонимах, поскольку этот пласт лексики никем еще не рассматривался. Проведенный обзор свидетельствует о том, что нарицательными словами, употребляющимися в данном значении, может выступать целый ряд лексем. Автором выявлено в общей сложности 13 единиц, учитывая разные варианты. Этимологический анализ проанализированных географических терминов позволяет сделать вывод, что по происхождению они неоднородны. Самыми распространенными являются апеллятивы, заимствованные из русского языка. Несколько меньшую частоту употребления имеют географические термины удмуртского и допермского или финно-пермского происхождения. Незначительное количество составляют лексемы, восходящие к тюркским языкам. Смешанные удмуртско-русские и удмуртско-татарские образования представлены в единичном количестве.

Ключевые слова: удмуртский язык, микротопонимия, годонимы, годонимическая лексика, географические термины, апеллятивы, слова для обозначения улиц и переулков, финно-угорские языки, языковые контакты, этимология географических терминов.

DOI: $10.35634 / 2224-9443-2021-15-4-576-589$

В населенных пунктах, независимо от того, городские они или сельские, есть улицы и переулки. Они, подобно другим географическим объектам, имеют свои собственные имена, называемые в топонимике годонимами (от греч. ó ós 'путь, дорога, улица, русло' + оним 'имя, название') [Подольская 1988, 52]. В статье рассматриваются географические термины, функционирующие при образовании названий улиц и переулков, зафиксированных в местах проживания удмуртов, например: вил'/урам (ул., д. Чемошур-Куюк Алн. ${ }^{1}$ ) (букв. 'новая улица') [ПМА, 2004]; зӧк/ул'ча (ул., д. Золотарево Глаз.) (букв. 'большая улица') [ПМА, 2002]; гэнис/ пролка (пер., д. Пычанки Зав.) (букв. 'переулок Дениса') [ПМА, 2002]; микон/кож (пер., д. Дубровский Кияс.) (букв. 'переулок Никона') [ПМА, 1999]. Основным источником для исследования послужили полевые материалы автора (сокр. ПМА), собранные, главным образом, в уд-

\footnotetext{
${ }^{1}$ После микротопонима в скобках в сокращенном виде указан тип географического объекта, затем - сокращенное название населенного пункта и административного района Удмуртии и других регионов (полные названия представлены в Списке сокращений в конце статьи).
} 
муртских и частично в удмуртско-русских населенных пунктах Удмуртской Республики и соседних регионов. Привлечен для анализа также фактический материал из монографий Л. Е. Кирилловой [Кириллова 1992; Кириллова 2002], М. А. Самаровой [Самарова 2010], топонимического словаря М. Г. Атаманова [Атаманов 2015], кроме того, использованы дипломные (квалификационные) исследования студентов факультета удмуртской филологии Удмуртского государственного университета ${ }^{2}$.

Анализ научной литературы о системе планировки населенных пунктов позволяет сделать вывод, что «наиболее древней формой восточнославянского поселения является, повидимому, кучевая, или, правильнее, гнездовая, для которой характерно беспорядочное расположение строений группами, кучками и нередко на беспорядочном расстоянии одно от другого» [Бломквист 1956, 41]. Это было присуще и для удмуртских поселений. Ссылаясь на статью В. Шестакова [Шестаков 1859, 75], утверждавшего, что «по сведениям 1858 года, из 1156 населенных пунктов Глазовского уезда (Вятской губернии, ныне Удмуртской Республики - Л. К.) 443 имели беспорядочную планировку», удмуртский этнограф Г. К. Шкляев предполагает, что это были удмуртские поселения [Шкляев 1981, 40-41], поскольку русские населенные пункты к середине XIX в. приобрели уже уличную планировку [Бломквист 1956, 49]. Изменения в поземельном устройстве сельских общин российских деревень, вызванные проникновением капиталистических отношений, привели к внедрению уличной планировки. Известную роль в возникновении уличного типа селений сыграли специальные законы и постановления царского правительства, касающиеся перепланировки и перестройки деревень России [Бломквист 1956, 49-56], а после реформы 1861 г. были проведены параллельные и перпендикулярные улицы и переулки [Бломквист 1956, 50]. Подобные тенденции в развитии сельских поселений свойственны и для территории Удмуртии. Однако на данной территории «наблюдалось отставание в развитии отдельных социально-экономических явлений, что было вызвано политикой царского правительства, направленной на искусственное сдерживание развития и сохранение феодально-патриархальных пережитков в среде нерусских народов» [Шкляев 1981, 41]. Из этого следует, что улицы и переулки на территории Удмуртии могли появиться позже, нежели на территории Центральной России.

Для обозначения улиц в удмуртском языке и его диалектах используются слова ульча и урам, и этот вопрос более или менее уже изучен (см. об этом ниже). А для выражения понятия 'переулок' в удмуртских диалектах и говорах функционирует целый спектр апеллятивов, которые не получили освещения в удмуртском языкознании, по топонимическим же материалам это хорошо прослеживается. В статье сделана попытка очертить границы распространения рассматриваемых апеллятивов, раскрывается их этимология.

\section{Географические термины для обозначения улицы}

В словарях русского языка понятие улища объясняется следующим образом: «Улица - околица; простор меж двух порядков домов; полоса, проезд, дорога, оставляемая промеж рядами домов» [Даль 1996 IV, 489]; «Улица - пространство между двумя рядами домов в населенном пункте для прохода или проезда; два ряда домов с проходом, проездом между ними» [СРЯ 1984 IV, 486; СТСРЯ 2004, 866]; «Улица - в населенных пунктах: два ряда домов и пространство между ними для прохода и проезда, а также само это пространство» [Ожегов 1989, 828]. В удмуртском литературном языке и во многих диалектах для обозначения улиц используются слова ульча и урам, что широко отразилось и в микротопонимии, например: вамэн/ул'ча (дд. Гамберово, Кочегурт Селт.) (вамэн 'поперечный', букв. 'поперечная улица') [Кириллова

\footnotetext{
${ }^{2}$ Использован материал из дипломных (квалификационных) работ Ившиной А. И. (д. Каравай Яр.), Корнилова Д. Л. (с. Ошторма-Юмья Кукм. РТ), Набиуллиной Л. А. (д. Каймашабаш Ян. РБ), Нуриахметовой Р. Ш. (с. Барабановка, дд. Будзи-Варяш, Можга, Няняды, Старый Варяш, Шудек Ян. РБ), Осиповой Е. П. ( дд. Качкин-Турай, Малый Качак Калтас. РБ), Раяновой Р. И. (дд. Касиярово, Старотазларово Бур. РБ), Тимиргалиевой С. Г. (с. Барабановка Ян. РБ), Тимирхановой С. В. (д. Большое Туганеево Калтас. РБ), Харитоновой (Ивановой) В. А. (д. Суроново Шарк).
} 
2002, 96]; зӧк/ул'ча (д. Золотарево Глаз.) (зӧк ‘большой’, букв. 'большая улица') [ПМА, 2000]; лулnу/ул'ча (д. Старые Кены Зав.) (лулnу 'ольха, ольховый', букв. 'ольховая улица') [ПМА, 1995]; бигбай/урам (с. Можга Можг.) (бигбай - д. Бикбай Можг., т. е. 'улица, расположенная в стороне д. Бикбай’) [Кириллова 1992, 204]; гурэз'/йъл/урам (д. Колошур Кияс.) (гурэз' 'гора', йыл - послелог 'на', т. е. 'улица на горе') [ПМА, 1999]; курэг/урам (д. Кузебаево Алн.) (курэг - прозвище человека < курэг 'курица', т. е. 'улица, на которой живет человек по прозвищу Курег (Курица)’ [ПМА, 2003] и т. д.

Что касается происхождения данных апеллятивов, первый из них заимствован из русского языка и восходит к слову улица, а второй - из тюркских языков, ср. башк., тат., чув. урам 'улица' [РБС; ТРС 2007 II, 479; ЧРС 1982, 515]. Лексема ул'ча представлена, главным образом, в северных и срединных говорах Удмуртии, а урам - в собственно южных, периферийно-южных, частично - в срединных говорах удмуртского языка, а также у удмуртов, проживающих в районе нижнего и среднего течения р. Кильмезь. Дистрибуция данных лексем и их вариантов в диалектах и говорах удмуртского языка наглядно представлена на карте, опубликованной в «Диалектологическом атласе удмуртского языка» [ДАУЯ 2009 I, 214] (см. карту в конце статьи), а в комментариях к карте «Улица» рассмотрены вопросы происхождения этих лексем и их фиксации в письменных источниках [Насибуллин 2009, 188-189]. Лексема ул'ча в удмуртских письменных памятниках впервые фиксируется в 1785 г. в словаре 3. Кротова [Насибуллин 2009,188 ], а слово урам выявляется в источниках лишь в конце ХІХ в. [Насибуллин 2009, 189].

Во многих финно-угорских языках слово с семантикой 'улица' также является русским заимствованием и функционирует в следующих формах: эрз. ульия: Ало ульия (букв. 'нижняя улица') (с. Черная Промза ББ РМ) [Цыганкин 2005, 22]; Базар ульияя (букв. 'базарная улица') (д. Болдасево Ич. РМ) [Цыганкин 2005, 34]; моки. ульия, ульияня: Лесной ульия ('лесная улица') (с. Теплый Стан ЗП РМ) [Казаева 2005, 48]; Пакся ульияня ('улица рядом с полем') (с. Курташки Атюр. РМ) [Цыганкин 2005, 261]; в эрзя-мордовских говорах Самарской области улься: Икельс улься ('передняя улица') (с. Мордово-Абеляково Исакл. Самар. обл.) [Беленов $2020,82]$. В коми языке известно слово улича [РКС 2003, 997]: Куратов улича (улица Куратова), Печора улича (Печорская улица) (г. Сыктывкар Республика Коми); в коми-пермяцком - улица, улича [КПРС 1985, 512]. В марийском языке для обозначения данной реалии используется заимствованное из тюркских языков слово урем: Первомайский урем (улица Первомайская), Эипай урем (улица Эшпая) (г. Йошкар-Ола) [БМРС], в диалектах встречаются формы урем и орем: Керемет урем (букв. 'Семейного мольбища улица') (д. Мари-Возжай Грах. УР); Кӱшыл орем (букв. 'Верхняя улица') (д. Мари-Сарамак Кизн. УР) [Вершинин 2005, 57, 70]. В горномарийском языке употребляется апеллятив ӧлицӓ, восходящий к рус. улища: Матьыве ӧлищӓ ('Матвеева улица') (д. Алёшкино ГМар. РМЭ); Часовня ӧлииӓ ('улица часовня’) (д. Носёлы ГМар. РМЭ) [Васикова 2003, 170, 307].

В населенных пунктах дома чаще всего расположены двумя рядами. Это так называемые двусторонние улицы, или двусторонки. В удмуртском языке такие улицы называют просто ул'ча или урам, не конкретизируя при этом, во сколько рядов расположены дома.

Иногда встречаются такие улицы, где дома располагаются лишь с одной стороны. В русском языке их называют сочетанием односторонняя улица, или улица-односторонка. В удмуртской топонимии для обозначения данного понятия используется географический термин пал ул'ча / пал урам (пал 'пол-, полу-, одно-', 'непарный') или палнала ул'ча / палнала урам (палнала 'однобокий; половинчатый').

\section{Апеллятивы для обозначения переулков}

Вторая группа апеллятивов, встречающихся в годонимах, - это слова для обозначения переулков. В словарях русского языка даны следующие определения: «Переулок - небольшая улица, обычно служащая поперечным соединением двух других улиц» [Ожегов 1989, 510; СРЯ 1984 III, 103; СТСРЯ 2004, 518]; «Переулок - поперечная улка; короткая улица, для связи улиц 
продольных» [Даль 1996 III, 94]. Данные определения, как нам кажется, не совсем точные. Для городских объектов они более или менее приемлемы. Для сельских же, по нашему мнению, нужно внести некоторые коррективы. Во-первых, переулок может обозначать небольшую, в несколько домов улицу, соединяющую другие, не всегда параллельные, иногда и перпендикулярно или под каким-либо углом расположенные улицы. Во-вторых, переулок может обозначать небольшую улицу, отходящую от какой-либо единичной улицы, размером побольше. Этот переулок может быть проходом для спуска к реке, может использоваться для прохода или проезда к другим географическим объектам, таким как ферма, кузница, гараж, поле, луг, лес и т. д., находящимся несколько в стороне от улиц или за деревней.

Топонимические данные свидетельствуют о большом разнообразии апеллятивов для обозначения понятия 'переулок'. Анализ микротопонимов, выявленных на территории Удмуртии и за ее пределами, в местах проживания удмуртов, позволяет выделить следующие географические термины для обозначения переулков: вис (виск-), залка, кож, кусып, пичи ул'ча, пичи урам, прогал $\sim$ прогай, прокод проход, пролка пройка п проулка $\sim$ пэролка $\sim$ проу:лок пролок, пэрэу:лок, тыккырык тъкърък, вӥрам.

Рассмотрим каждый из апеллятивов отдельно.

\section{вис (виск-)}

Удмуртская лексема вис (виск-), имеющая множество значений - ‘промежуток, интервал'; 'междурядье'; ‘щель, трещина'; ‘перерыв, антракт, пауза, передышка'; 'грань, граница, межа'; 'переулок’; 'перегородка' [УРС 2008, 123], - финно-пермского происхождения и восходит к слову wiskз с семантикой 'промежуток, интервал', cp. мар. wiš 'открытый'; 'просека, прогалина, лесная поляна'; 'промежуток, интервал'; кз. vis (visk-) 'ручей между озером и рекой’; ‘название реки между озером и рекой', 'плотина (запруда) из хвороста в канаве между речным заливом и рекой' [UEW 1988 7, 823]. Все значения вышеназванных слов так или иначе связаны с понятием 'местоположение объекта между чем-либо'. Так и лексема переулок восходит к такой же семантике - 'географический объект, расположенный между улицами или между улицей и другим каким-либо географическим объектом’.

Географический термин с семантикой 'переулок' зафиксирован в микротопонимах Можгинского и Сюмсинского районов: быркыт/вис (д. Большие Сибы Можг.) (быркыт - прозвище человека < быркыл 'беркут, орел', букв. 'переулок Быркыта') [Кириллова 1992, 206]; nucлэг/вис (д. Большие Сибы Можг.) (пислэг - др.-удм. личное имя < пислэг 'синица'; в этом переулке жил мужчина по имени Пислэг) [Кириллова 1992, 235]; пичи/вис (д. Балма Сюмс.) (пичи 'маленький', букв. 'маленький переулок') [Кириллова 2002, 276] и т. д.

Нужно отметить, что кроме этого значения слово вис в удмуртских микротопонимах может еще выражать понятие 'граница, межа'; в частности, в деревнях Можгинского района нами зафиксировано несколько таких названий, например: c'uбbl/вис (c'uбы - д. Большие Сибы Можг., т. е. 'граница, межа между земельными угодьями дд. Почешур и Большие Сибы') [Кириллова 1992, 243]; чимошур/вис (чимошур - д. Верхний Чемошур Можг., т. е. 'граница, межа между земельными угодьями дд. Почешур и Верхний Чемошур’) [Кириллова 1992, 250] и т. д.

\section{залка заўка заулка}

Восходит к рус. заулок < за- + улок (заулок - 'переулок, проулок, глухая улка, закоулок; тесная, пешая улка' [Даль 1989 I, 656]). Выявлен в Кизнерском, Можгинском, Сюмсинском районах, например: ӟуч/пӧбйа/залка (д. Удмуртская Бабья Сюмс.) (ӟуч/пӧбйа - д. Русская Бабья Сюмс. - по этому переулку ходили (ездили) в д. Русская Бабья) [Кириллова 2002, 153]; окыл'на/ заукка (д. Безменшур Кизн.) (окыл'на < рус. Акилина - личное имя женщины, дом которой стоял в этом переулке) [Атаманов 2015, 590]; ос'а/заулка (д. Нынек Можг.) (ос'a < рус. мужское лич- 
ное имя Иосиф < греч. < др.-евр., букв. 'Осин переулок' или 'переулок, где живет Иосиф и его семейство' [Атаманов 2015, 596]).

\section{коюс}

Это слово удмуртского происхождения и генетически связано с удм. кожыны 'завернуть (свернуть) в сторону, посторониться', т. е. переулок - это географический объект, расположенный в стороне от улицы. В удмуртском литературном языке и во многих диалектах слово кож имеет другую семантику - 'омут, излучина реки'.

Апеллятив кож с семантикой 'переулок' выявлен в микротопонимии некоторых деревень Киясовского района Удмуртии и Янаульского, Бураевского районов Республики Башкортостан: алдар/кож (д. Каймашабаш Ян. РБ) (алдар - мужское личное имя; переулок расположен рядом с хозяйством Алдара); микон/кож (д. Дубровский Кияс.) (микон - удм. форма рус личного имени Никон; в начале переулка стоял дом Никона) [ПМА, 1999]; с'идор/кож (д. Касиярово Бур. РБ) (с'идор - мужское личное имя; в этом переулке жил Сидор) [Садиков 2004, 81]; склат/пала/тубон/кож (д. Карамас-Пельга Кияс.) (склат < склад 'склад', пала - послелог 'к', тубон - сущ. от глаг. тубыны 'подняться, подниматься'; по этому переулку ходили на склад) [ПМА, 1999]; трыпка/кож (с. Барабановка Ян. РБ) (трыпка < рус. трубка, т. е. 'переулок, похожий на трубку') и др. Следует отметить, что в д. Касиярово Бур. РБ кроме апеллятива кож встречается и заимствованный из тюркских языков географический термин тыкырык [Садиков 2004, 81] (см. об этом ниже).

\section{кycbin}

В микротопонимии деревень Алнашского, Граховского районов Удмуртии, Калтасинского района Республики Башкортостан широко известно функционирование этого апеллятива с семантикой ‘переулок’, т. е. ‘небольшая улица между другими улицами, размером побольше', например: баӟӟым/кусыл (д. Большое Туганеево Калтас. РБ) (баӟӟым ‘большой', букв. 'большой переулок'); оддок/кусъп (д. Кузюмово Алн.) (оддок - удм. форма рус. личного имени Евдоким, букв. 'переулок Евдокима') [ПМА, 2004 ]; такйанай/кусып (д. Новый Утчан Алн.) (такйанай - удм. форма рус. личного имени Татьяна; в начале переулка стоит дом Татьяны Петрушиной) [ПМА, 2008]; шл'аган/кусып (д. Чемошур-Куюк Алн.) (ил'аган - прозвище Петрова Павла; переулок находится рядом с его домом) [ПМА, 2004]; шӓкыр/кусып (д. Качкин-Турай Калтас РБ) (шӓкыр - мужское личное имя Шакир < тюрк. < араб. [Саттар-Мулилле 2006, 342]; в этом переулке живет Шакир); пильлn/кусыл (д. Старая Игра Грах.) (пилыл < рус. личное имя Филипп; 'переулок, где живет семейство Филиппа Воронцова' [Атаманов 2015, 627]).

В удмуртском литературном языке и в диалектах слово кусып употребляется со значением 'промежуток, расстояние, дистанция, интервал'. Имеет соответствия в кз. кост 'промежуток, расстояние (между какими-л. предметами’; ‘промежуток времени (между чем-л.)', ‘интервал’, 'пауза', 'зазор'; основа послелогов костын 'между (в промежутке)', костӧ, kos 'между (в промежуток)'; кя. kost и kosp. Общеперм. *kosip и *kost- 'промежуток', 'между', - $p$ и -t- суффиксы. Барци сопоставляет эти слова с венг. küszöb ‘порог'. Доперм. *kӥs̈̈р 'промежуток', ‘между’ [КЭСК 1999, 134-135].

\section{пичи/ул'ча, пичи/урам}

Нередко сочетания пичи/ул'ча и пичи/урам (пичи 'маленький', ул'ча урам 'улица', букв. 'маленькая улица') используются для обозначения переулков и функционируют как названия небольших улиц, например: пичи/ул'ча (ул., д. Толошур Селт. [Кириллова, 2002, с. 355]); пичи/ урам (ул., с. Барабановка, дд. Будзи-Варяш, Можга, Няняды, Старый Варяш, Шудек Ян РБ). 


\section{прогал прогаў}

Слово восходит к рус. прогал (прогал 'промежуток между чем-л.' [СРЯ 1984 III, 474]). В топонимии Удмуртии является широко распространенным географическим термином, выявлен в Балезинском, Вавожском, Дебесском, Игринском, Красногорском, Можгинском, Селтинском, Сюмсинском, Увинском, Якшур-Бодьинском, Ярском районах Удмуртии и в Кильмезском районе Кировской области. Примеры: зун/прогал (д. Бадзимлуд Сюмс.) (зун - с. Зон Сюмс., т. е. 'переулок, по которому ходили (ездили) в с. Зон') [Кириллова 2002, 147]; клуn/ прогал (д. Большой Гозек Кильм. Кир. обл.) (клуn < клуб; в этом переулке находился клуб) [ПМА, 2015]; кэбит/nал/прогал (д. Варавай Красн.) (кэбит 'кузница', пал - послеложная основа 'в стороне', т. е. 'переулок в стороне кузницы') [Кириллова 2002, 216]; микола/прогал (д. Лынвай Як-Б.) (микола - удм. форма рус. личного имени Николай, букв. 'переулок Николая') [Кириллова 2002, 240]; подмошур/прогал (д. Нововолково Балез.) (подмошур - название речки, т. е. 'переулок, по которому спускались к речке Подмошур') [ПМА, 2001]; поскотн'a/nрогал (д. Шушангурт Игр.) (поскотн'а 'поскотина', т. е. 'переулок, по которому выгоняли скот на поскотину’) [Кириллова 2002, 288]; прогал (д. Меметово Яр. [МРТК-І], д. Роготнево Деб. [Самарова 2010, 222]); прогай (д. Большие Сибы Можг., д. Малая Можга Вав.) [Кириллова 1992, 238]; шор/бусыл/прогал (д. Чашкагурт Селт.) (жор/бусы - название поля (букв. 'среднее поле'), т. е. 'переулок, по которому ходили (ездили) на Среднее поле’ [Кириллова 2002, 380].

\section{прокод проход}

Апеллятив восходит к рус. проход (проход 'место, по которому можно пройти через что-л., между чем-л.' [СТСРЯ 2004, 649]). В слове прокод не свойственный удмуртскому языку звук $x$ заменяется согласным $\kappa$, как, например, и в таких словах: ол'ка < рус. ольха, пастук < рус. пасmух, Тикон < рус. Тихон, калат < рус. халат, кирург < рус. хирург и т. д. Встречается в Глазовском и Балезинском районах: кондрат/проход (д. Качкашур Глаз.) (кондрат < рус. Кондратий; дом Кондратия стоял у этого переулка) [МРТК-І]; парампи/проход (д. Нурызово Балез.) (парам$n u$ - патроним, т. е. 'переулок возле дома сына Парама') [MРТК-I]. М. А. Самарова записала подобные наименования в Дебесском, Игринском и Шарканском районах, например: вуко/проход (д. Петухи Шарк.) (вуко 'мельница', т. е. 'переулок, в конце которого стояла мельница'); киз'на/прокод (д. Ягвай Деб.) (киз'на - д. Малая Кизня Деб., т. е. 'переулок в стороне д. Малая Кизня'); ошмэс/проход (д. Гордъяр Деб.) (ошмэс 'родник', т. е. 'переулок, по которому ходили на родник'); прокод/н'ук (д. Малый Зетым Игр.) (н'ук 'лог, овраг', букв. 'лог в переулке') [Самарова 2010, 178, 195].

\section{пролка проўка проулка пэролка проу॰лок пролок}

Этот апеллятив с разными вариантами функционирования является заимствованием из русского языка (< рус. проулок проулка 'небольшой, узкий переулок'). Формы пролка пройка проулка отличаются самой широкой распространенностью по сравнению с другими апеллятивами с данной семантикой. Встречается в микротопонимии сел и деревень Вавожского, Завьяловского, Игринского, Киясовского, Малопургинского, Можгинского, Селтинского, Увинского, Шарканского, Якшур-Бодьинского районов Удмуртии и в д. Варклед-Бодья Агрызского района Татарии, например: баз̆ӟьлм/nролка (д. Ольховка Ув.), баз̆ӟьлм/проўка (с. Большая Уча Можг.) (баӟӟым 'большой', букв. 'большой переулок') [Кириллова 1992, 203]; вало/дурэ/вас'кон/ пролка (д. Чудзялуд Вав.) (вало - удм. название реки Вала, дурэ - послелог 'к', вас'кон - сущ. от глаг. вас'кыны 'спускаться', т. е. 'переулок, по которому спускаются к реке Вале') [Кириллова 1992, 208]; йако/пролка (д. Дубровский Кияс.) (йако - удм. форма рус. личного имени Яков; на краю переулка стоял дом Якова) [ПМА, 1999]; клубэ/вас'кон/пролка (д. Варклед-Бодья Агр. РТ) (клу- 
бэ < клуб 'клуб' + -э - суф. входного падежа, вас'кон - сущ. от глаг. вас'кыныь 'спускаться', т. е. 'переулок, по которому спускаются в клуб') [ПМА, 1999]; л'нозаводэ/мынон/пролка (д. Пажгурт Селт.) (л'нозаводэ < л'нозавод - пос. Льнозаводский Селт. + -э - суф. входного падежа, мынон - сущ. от глаг. мыныны 'идти, ехать', т. е. 'переулок, по которому ездили (ходили) в пос. Льнозаводский’) [Кириллова 2002, 228]; ошмэс/пролка (д. Суроново Шарк.) (ошмэс 'родник'; т. е. 'переулок, по которому ходили на родник') и т. д.

Формы проу:лок пролок пэролка характеризуются меньшим распространением. Зафиксированы они в микротопонимии Дебёсского, Игринского и Сюмсинского районов Удмуртии и Кильмезского района Кировской области: аким/пролок (д. Сундур Игр.) [Самарова 2010, 169] (аким - мужское личное имя, букв. 'переулок Акима'); зойа/сm'эnанова/бортти/проулок (д. Варни Деб.) [Самарова 2010, 173] (зойа сm'эnанова - имя и фамилия человека, бортти - послелог 'рядом', т. е. 'переулок рядом с домом Зои Степановой'); клуn/проулок (д. Удмурт Лоза Игр.) [Самарова 2010, 196] (клуn < рус. клуб, т. е. 'переулок рядом с клубом'); пожсарной/ проу:лок (д. Удмуртская Бабья Сюмс.; в этом переулке стоял пожарный сарай) [Кириллова 2002, 281]; проулок (д. Паска Кильм. Кир. обл.) [ПМА, 2015]. В д. Байвал Игринского района выявлено несколько микротопонимов с географическим термином пэролка: пичи/иван/nэролка (пичи/иван - прозвище < пичи 'маленький', иван - мужское личное имя, букв. 'переулок Маленького Ивана'); пэролка/ошмэс (ошмэс 'родник', букв. 'родник в переулке') и др. [Самарова 2010, 218, 224].

Географический термин пролок встречается и в микротопонимии деревень Асавка Балтачевского и Старый Кызыл-Яр Татышлинского районов Башкирии.

\section{пэрэу:лок}

Раньше это слово больше употреблялось в смешанных русско-удмуртских деревнях, но в последнее время оно часто начало функционировать и в удмуртских селениях в связи с введением в населенных пунктах официальных наименований улиц и переулков, например: мӓрйӓм/пэрэулок (д. Старотазларово Бур. РБ) (мӓрйӓм - антропоним татарского происхождения, букв. 'переулок Марьяма'); пэрэулок/л'эн'ина 'переулок Ленина' (с. Большая Уча Можг.) [Кириллова 1992, 228]; прудовый/пэрэулок 'Прудовый переулок' (д. Башур Зав.) [ПМА, 1995]; садовый/пэрэулок 'Садовый переулок’ (д. Якшур Зав.) [Зверева 1980, 144] и т. д.

\section{тыкрык тыкырык т тъкърък}

Этот географический термин в различных диалектных вариантах по происхождению является заимствованием из тюркских языков, ср. башк. тылкрык 'переулок, тупик (улицы)' [РБС], тат. тыкырык 'переулок', диал. этногр. 'промежуток между усадьбами (при круговом расселении, бывшем в древности), диал. тупик, закоулок’ [ТРС 2007 II, 454], чув. тӑкӑрлӑк ‘переулок' [ЧРС 1982, 453].

Этот апеллятив зафиксирован в микротопонимии некоторых удмуртских деревень Респуб-

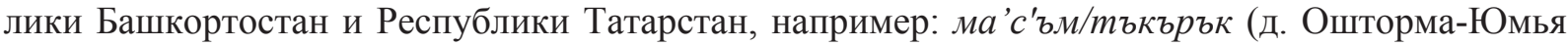
Кукм. РТ) (ма' 'с'вм - личное имя < рус. Максим; возле этого переулка жил Максим); Гарасьпролтыкрык (с. Покровский-Урустамак Бавл. РТ) (Гарась < рус. личное имя Герасим, Прол < рус. личное имя Фрол, 'переулок, где живет Фрол Герасимов') [Атаманов 2015, 233]; лафка/ тыкылылк (д. Касиярово Бур. РБ) ('магазинный переулок’); кос'та/тыкылрык (д. Малый Качак Калтас. РБ) (кос'ma < рус. Константин; в начале переулка живёт Константин) и т. д.

Отметим, что в некоторых говорах для обозначения переулка, соединяющего две улицы, используется одно слово, а для переулка, являющегося проходом для спуска к реке, - другое. Так, в деревнях Асавка Балтач. РБ и Старый Кызыл-Яр Татышл. РБ в первом случае употребляется лексема пролок (о происхождении см. выше), а во втором случае - вӥрам (по устному 
сообщению В. Г. Зидымышевой, 1975 г. рожд., уроженки д. Старый Кызыл-Яр, учительницы Июльской средней школы Воткинского района Удмуртии). В селах Нижнебалтачево и Уразгильды Татышл. РБ функционирует лишь слово вӥрам (по устному сообщению А. Т. Байдуллиной, 1971 г. рожд., уроженки с. Уразгильды, журналистки республиканской газеты «Ошмес» в Башкортостане). Апеллятив вӥрам удмуртского происхождения, восходит к сочетанию слов вӥ 'вода, река' и урам 'улица', т. е. 'улица, по которой идут к реке (или за водой)'.

\section{Заключение}

Сбор и анализ микротопонимов удмуртских деревень Удмуртской Республики и сопредельных территорий позволяют выявить немалое количество географических терминов для обозначения улиц и переулков. Для выражения понятия 'улица' в удмуртской микротопонимии используются заимствованные лексемы ул'ча (< рус. улища) и урам (< тюрк. урам). Семантическое поле 'переулок' характеризуется большим количеством лексем, о чем ярко свидетельствуют топонимические данные. В результате анализа собранной микротопонимии нами выявлены в общей сложности 13 географических терминов с разными вариантами. Характер их происхождения и количество неоднородны (см. табл. 1):

Таблица 1

Происхождение и количество географических терминов для обозначения переулков

\begin{tabular}{|c|c|c|}
\hline $\begin{array}{c}\text { Происхождение } \\
\text { географических терминов }\end{array}$ & $\begin{array}{c}\text { Количество } \\
\text { географических } \\
\text { терминов } \\
\end{array}$ & $\begin{array}{c}\text { Географические термины } \\
\text { и их варианты }\end{array}$ \\
\hline $\begin{array}{l}\text { заимствованные из тюркских } \\
\text { языков }\end{array}$ & 1 & тылкрык $\sim$ тылкырык $\sim$ тъкърък \\
\hline удмуртского происхождения & 2 & кож, вӥрам \\
\hline $\begin{array}{l}\text { допермского или финно- } \\
\text { пермского происхождения }\end{array}$ & 2 & вис (виск-), кусыл \\
\hline $\begin{array}{l}\text { заимствованные } \\
\text { из русского языка }\end{array}$ & 6 & $\begin{array}{c}\text { залка, прогал } \sim \text { прогай, прокод } \sim \\
\text { проход, пролка } \sim \text { проўка } \sim \text { проулка } \sim \\
\text { пэролка, проу:лок } \sim \text { пролок, пэрэу:лок }\end{array}$ \\
\hline удмуртско-русские & 1 & пичиул'ча \\
\hline удмуртско-татарские & 1 & пичиурам \\
\hline Итого: & 13 & \\
\hline
\end{tabular}

К сожалению, не вся территория проживания удмуртов фронтально обследована, в удмуртском языкознании нет работ, касающихся вопросов происхождения и функционирования лексем для обозначения переулков. Не исключено, что дальнейшее исследование удмуртских диалектов и топонимии позволит выявить еще какие-либо слова для обозначения данной реалии.

Лингвистические данные свидетельствуют о том, что слова для обозначения улиц являются более древними по сравнению со словами, выражающими понятие 'переулок'. Доказательством этого является тот факт, что во многих языках слова с семантикой 'переулок' являются производными от слова улица, например: рус. закоулок 'небольшой, узкий, глухой переулок' (< за- + ко- + улок, букв. 'то, что примыкает к улице') [БЭСРЯ 2018, 149]; переулок (< пере- + улок); проулок (< про- + улок); мар. изурем 'переулок, маленькая улочка' [БМРС] (< изи 'маленький; небольшой по величине, объему, размеру', ypeм 'улица'); англ. bystreet и side-street 'переулок' [САРРАС 2010, 437] (bystreet < by 'y, при, около; вдоль', street 'улица', 
букв. 'при улице, около улицы'; side-street side 'бок, боковой', street 'улица', букв. боковая улица'); венг. mellekutca и kis utca 'переулок' [ОМК 1975, 591] (mellekutca < mellek 'боковой', utca 'улица', букв. 'боковая улица'; kis utca < kis 'маленький', utca 'улица', букв. 'маленькая улица'); фин. sivukatu 'переулок, закоулок, глухая улица' [SVS 1995, 573] (< sivu 'сторона; мимо, стороной', katu 'улица'); эст. põiktänav 'переулок; проезд’ [EVS 1974, 421] (< põik< põikama 'свернуть, сворачивать', tänav 'улица') и т. д.

\section{СОКРАЩЕНИЯ}

Административно-территориальные районы Удмуртии: Алн. - Алнашский; Балез. - Балезинский; Вав. - Вавожский; Глаз. - Глазовский; Грах. - Граховский; Деб. - Дебесский; Зав. - Завьяловский; Игр. - Игринский; Кизн. - Кизнерский; Кияс. - Киясовский; Красн. - Красногорский; Можг. - Можгинский; Селт. - Селтинский; Сюмс. - Сюмсинский; Ув. - Увинский; Шарк. - Шарканский; Як.-Б. - Якшур-Бодьинский; Яр - Ярский.

Административно-территориальные районы других регионов: Агр. РТ - Агрызский р-н Республики Татарстан; Атюр. РМ - Атюрьевский р-н Республики Мордовия; Бавл. РТ - Бавлинский р-н Республики Татарстан; Балтач. РБ - Балтачевский р-н Республики Башкортостан; ББ РМ - Большеберезниковский р-н Республики Мордовия; Бур. РБ - Бураевский р-н Республики Башкортостан; ГМар. РМЭ - Горномарийский р-н Республики Марий Эл; ЗП РМ - ЗубовоПолянский р-н Республики Мордовия; Исакл. Самар. обл. - Исаклинский р-н Самарской обл.; Ич. РМ - Ичалковский р-н Республики Мордовия; Калтас. РБ - Калтасинский р-н Республики Башкортостан; Кильм. Кир. обл. - Кильмезский р-н Кировской области; Кукм. РТ - Кукморский р-н Республики Татарстан; Татышл. РБ - Татышлинский р-н Республики Башкортостан; Унин. Кир. обл. - Унинский р-н Кировской области; Ян. РБ - Янаульский район Республики Башкортостан.

Tипы географических объектов: лг. - луг; д.- деревня; п. - поле; пос. - поселок; рчк. - речка; с. - село.

Языки и диалекты: араб. - арабский; башк. - башкирский; греч. - греческий; др.-евр. древнееврейский; др.-удм. - древнеудмуртский; рус. - русский; тат. - татарский; тюрк. - тюркский; удм. - удмуртский; чув. - чувашский.

Другие сокращения: букв. - буквально; глаг. - глагол; диал. - диалектное слово; оф. - официальное название; с. - страница; см. - смотри; ср. - сравни; суф. - суффикс; сущ. - существительное; т. - том; этногр. - этнографический (термин).

\section{ЛИТЕРАТУРА}

Атаманов М. Г. Язык Земли Удмуртской: историко-этимологический словарь топонимов ВолгоУральского региона. Ижевск: Ижевская республиканская типография, 2015. 976 с.

Беленов Н. В. Топонимическое пространство эрзя-мордовского села Мордово-Аделяково Самарской области // Современная наука: актуальные проблемы теории и практики. 2020. Серия: Гуманитарные нау-ки. № 12-3. С. 80-84.

Бломквист E. Э. Крестьянские постройки русских, украинцев и белорусов (поселения, жилища и хозяйственные строения) // Восточнославянский этнографический сборник. Очерки народной материальной культуры русских, украинцев и белорусов в XIX - начале XX в. М. 1956. С. 3-458. (Труды Института этнографии им. Михлухо-Маклая. Новая серия. Т. 31).

БМРС - Большой марийско-русский словарь. Режим доступа: https://dict.fu-lab.ru.

БЭСРЯ - Большой этимологический словарь русского языка / Сост. М. В. Климова. М.: Дом славянской книги, 2018. 960 с.

Васикова Л. П. Горномарийско-русский словарь географических названий / Мар. гос. ун-т. ЙошкарОла, 2003. 349 с.

Вершинин В. И. Словарь марийских топонимов низовья Камы и Вятки: Справочное издание. Йошкар-Ола: ООО «Стринг», 2005. 130 с.

Даль В. И. Толковый словарь живого великорусского языка. М.: Русский язык, 1978-1980. Т. 1-4. 
ДАУЯ - Диалектологический атлас удмуртского языка: Карты и комментарии / Насибуллин Р. Ш., Максимов С. А., Семёнов В. Г., Отставнова Г. В. Ижевск: НИЦ «Регулярная и хаотическая динамика», 2009. Вып. І. 260 с.

Зверева Л. Е. Микротопонимия деревни Якшур // Микроэтнонимы удмуртов и их отражение в топонимии. Ижевск: НИИ при Совете Министров Удмуртской АССР, 1980. С. 133-150.

Казаева Н. В. Апеллятивная лексика в топонимии Республики Мордовия. Саранск: Типография «Красный Октябрь». 2005. 152 с.

Кириллова Л. Е. Микротопонимия бассейна Валы (в типологическом освещении). Ижевск: УИИЯЛ УрО РАН. 1992. $320 \mathrm{c}$.

Кириллова Л. Е. Микротопонимия бассейна Кильмези. Ижевск: УИИЯЛ УрО РАН. 2002. 571 с.

КПРС 1985 - Коми-пермяцко-русский словарь / Сост. Р. М. Баталова, А. С. Кривощекова-Гантман. М.: Русский язык. 1985. 624 с.

КЭСК - Лыткин В. И., Гуляев Е. С. Краткий этимологический словарь коми языка. Сыктывкар. 1999. $430 \mathrm{c}$.

МРТК-I - Материалы I республиканского топонимического конкурса. Рукописный фонд Удмуртского института истории, языка и литературы Удмуртского Федерального исследовательского центра УрО РАН. Оп. 2-Н. д. № 255.

Насибуллин Р. Ш. Комментарий к карте «Улица» // Диалектологический атлас удмуртского языка: Карты и комментарии. Ижевск: НИЦ «Регулярная и хаотическая динамика», 2009. Вып. І. С. 188-189.

Ожегов С. И. Словарь русского языка. М.: Русский язык, 1989. 924 с.

Подольская Н. В. Словарь русской ономастической терминологии. М.: Наука. 1988. 192 с.

РБС - Русско-башкирский словарь [Электронный ресурс] / Под ред. З. Г. Ураксина. Уфа, 2005. Режим доступа: http://mfbl2.ru/mfbl/rusbash.

РКС 2003 - Безносикова Л. М., Забоева Н. К., Коснырева Р. И. Русско-коми словарь. Сыктывкар: Коми кн. изд-во. 2003. 1104 с.

Садиков Р. Р. Кисса гурт котырысь интынимъёс // Вордскем кыл. 2004. № 7 (109). 78-84-тй б.

Самарова М. А. Наименования топообъектов Верхней Чепцы. Ижевск: Удмуртский университет. 2010. $246 \mathrm{c}$.

САРРАС - Мюллер В. К. Современный англо-русский и русско-английский словарь. М.: ДОМ. XXI век: РИПОЛ классик. 2010. 541 с.

Саттар-Мулилле Г. Исемең матур, кемнәр куйган? Казан: Академия познания. 2006. 544 с.

СРЯ - Словарь русского языка: в 4-х т. / Под ред. А. П. Евгеньевой. М.: Русский язык. 1981-1984.

СТСРЯ - Современный толковый словарь русского языка / Гл. ред. С. А. Кузнецов. М.: Ридерз

Дайджест. 2004. 960 с.

ТРС 2007 - Татарско-русский словарь: в 2-х томах. Т. 2 (М - Я). Казань: Магариф. 2007. 726 с.

УРС 2008 - Удмуртско-русский словарь / Сост. Т. Р. Душенкова, А. В. Егоров, Л. М. Ившин и др.;

Отв. ред. Л. Е. Кириллова; РАН. УрО. Удм. ин-т ИЯЛ. Ижевск. 2008. 925 с.

Цыганкин Д. В. Память, запечатленная в слове: Словарь географических названий Республики Мордовия. Саранск: Типография «Красный Октябрь». 2005. 432 с.

ЧРС 1982 - Чувашско-русский словарь / Под ред. М. И. Скворцова. М.: Русский язык. 1982. 712 с.

Шестаков В. Глазовский уезд // Вестник Императорского Русского географического общества. 1859. № 7. C. $73-111$.

Шкляев Г. К. Из истории формирования сельского расселения и развития поселений на территории Удмуртии (XIX - нач. XX вв.) // Сельские поселения Удмуртии в XIX-XX вв.: Сборник статей. Ижевск: НИИ при Совете Министров Удмуртской АССР. 1981. С. 3-44.

EVS- J. Tamm. Eesti-vene sõnaraamat (= Эстонско-русский словарь). Tallinn: Valgus. 1974. 7661.

OMK 1975 - Gáldi László. Orosz-magyar kéziszótár (= Русско-венгерский словарь). Budapest: Akadémiai Kiadó, 1975. 1120 old.

SVS - Suomalais-venäläinen sanakirja (= Финско-русский словарь). Tekijät I. Vahros, A. Scherbakoff. Kolmas painos. Porvoo - Helsinki - Juva: Werner Söderström Osakeyhtiö, 1995. 816 s.

UEW - Rédei K. Uralisches etymologisches Wörterbuch. 7 Bände. Budapest: Akadémiai Kiadó, 1988. S. 733-906. 
Кириллова Людмила Евгеньевна, кандидат филологических наук, старший научный сотрудник, Удмуртский институт истории, языка и литературы УдмФИЦ УрО РАН, 426004, Россия, Ижевск, ул. Ломоносова, 4, e-mail: kirlud@rambler.ru.

\title{
L. J. Kirillova \\ HODONYMIC VOCABULARY IN THE UDMURT LANGUAGE (BASED ON THE MATERIAL OF TOPONYMY)
}

\author{
DOI: $10.35634 / 2224-9443-2021-15-4-576-589$
}

The article considers geographical terms for designating streets and lanes in the Udmurt language based on the study of a large corpus of godonyms. In the study of microtoponyms collected by the author and other toponymists on the territory of Udmurtia and beyond of it - in the places of residence of Udmurts - the author managed to identify a significant number of words expressing these concepts.

The words ulcha and uram are used to express the concept of 'street' in the Udmurt language, which is confirmed by the data of Udmurt toponymy. Special attention is paid to the description of common nouns with the meaning 'lane' recorded in microtoponyms, since this layer of vocabulary has not yet been considered in detail by anyone. The performed review indicates that a number of lexemes can act as common words used in this meaning. Taking into account different variants, the author identified 13 units in total. The etymological analysis of the analyzed geographical terms suggests that they are heterogeneous in origin. The common nouns borrowed from the Russian language are wide spread. Geographical terms of Udmurt and pre-Permian or Finno-Permian origin have a slightly lower frequency of use. A small number of lexemes are derived from the Turkic languages. Mixed Udmurt-Russian and Udmurt-Tatar formations are represented in a single number.

Keywords: the Udmurt language; microtoponyms; godonyms; godonymic vocabulary; geographical terms; common nouns; words for streets and lanes; the Finno-Ugric languages; language contacts; etymology of geographical terms.

Citation: Yearbook of Finno-Ugric Studies, 2021, vol. 15, issue 4, pp. 576-589. In Russian.

\section{REFERENCES}

Atamanov M. G. Yazyk Zemli Udmurtskoi: istoriko-etimologicheskii slovar' toponimov Volgo-Ural'skogo regiona [The language of the Udmurt Land: historical and etymological dictionary of the Volga-Ural region's toponyms]. Izhevsk: Izhevskaya respublikanskaya tipografiya Publ., 2015. 976 p. In Russian.

Belenov N. V. Toponimicheskoe prostranstvo erzya-mordovskogo sela Mordovo-Adelyakovo Samarskoi oblasti [Toponymic space of the Erzya-Mordovian village of Mordovo-Adelyakovo, Samara region]. Sovremennaya nauka: aktual'nye problemy teorii i praktiki. Seriya Gumanitarnye nauki [Modern Science: actual problems of theory and practice. Series of «Humanities»]. 2020. №. 12-3. P. 80-84. In Russian.

Blomkvist E. E. Krest'yanskie postrojki russkikh, ukraincev i belorusov (poseleniya, zhilishha i xozyajstvennye stroeniya) [Peasant buildings of Russians, Ukrainians and Belarusians (settlements, dwellings and farm buildings)]. Vostochnoslavyanskij etnograficheskij sbornik. Ocherki narodnoj material'noj kul'tury russkikh, ukraincev $i$ belorusov $v$ XIX-nachale XX v. [East Slavic ethnographic collection. Essays on the folk material culture of Russians, Ukrainians and Belarusians in the XIX - early XX century]. Moscow, (Trudy Instituta etnografii im. Mikhlukho-Maklaya. Novaya seriya. T. 31) [Proceedings of the Mikhlukho-Maklay Institute of Ethnography. New series. Vol. 31]. 1956. P. 3-458. In Russian.

BMRS - Bol'shoi marijsko-russkii slovar' [Big Mari-Russian Dictionary]. URL: https://dict.fu-lab.ru (accessed 20 February 2021). In Mari, Russian.

BESRYa-Bol'shoi etimologicheskii slovar' russkogo yazyka [Big etymological dictionary of the Russian language]. Comp. M. V. Klimova. Moscow: Dom slavyanskoi knigi Publ., 2018. 960 p. In Russian.

Vasikova L. P. Gornomariisko-russkii slovar' geograficheskikh nazvanii [Gornomariysk-Russian dictionary of geographical names]. Yoshkar-Ola, Mari State University Publ., 2003. 349 p. In Mari, Russian. 
Vershinin V. I. Slovar' marijskikh toponimov nizov'ya Kamy i Vyatki: Spravochnoe izdanie [The Dictionary of Mari toponyms of the lower reaches of the Kama and Vyatka: Reference edition]. Yoshkar-Ola: String Publ., 2005. 130 p. In Russian.

Dal' V. I. Tolkovyi slovar' zhivogo velikorusskogo yazyka [The Explanatory Dictionary of the Living Great Russian Language]. Moscow: Russkii Yazyk Publ., Vol. 1-4. 1978-1980. In Russian.

DAUYa - Dialektologicheskij atlas udmurtskogo yazyka: Karty i kommentarii [Dialectological atlas of the Udmurt language: Maps and comments.]. Comp. by Nasibullin R. Sh., Maksimov S. A., Semyonov V. G., Otstavnova G. V. Izhevsk: NITs Regulyarnaya i khaoticheskaya dinamika Publ., 2009. Iss. I. 260 p. In Russian.

Zvereva L. E. Mikrotoponimiya derevni Yakshur [Microtoponymy of the Yakshur village]. Mikroetnonimy udmurtov $i$ ikh otrazhenie $v$ toponimii [Microethnonyms of the Udmurts and their reflection in toponymy]. Izhevsk: Research Institute under the Council of Ministers of the Udmurt ASSR. 1980. P. 133-150. In Russian.

Kazaeva N. V. Apellyativnaya leksika v toponimii Respubliki Mordoviya [Appellative vocabulary in the toponymy of the Republic of Mordovia]. Saransk: Krasnyi Oktyabr' Publ., 2005. 152 p. In Russian.

Kirillova L. E. Mikrotoponimiya basseyna Valy (v tipologicheskom osveshchenii) [Microtoponymy of the Vala basin (in typological coverage)]. Izhevsk: Udmurtian Institute of History, Language and Literature of the Udmurt Federal Research Center of the Ural Branch of the Russian Academy of Sciences. 1992. 320 p. In Russian.

Kirillova L. E. Mikrotoponimiya basseyna Kilmezi [Microtoponymy of the Kilmesi basin]. Izhevsk: Udmurtian Institute of History, Language and Literature of the Udmurt Federal Research Center of the Ural Branch of the Russian Academy of Sciences, 2002. 571 p. In Russian.

KPRS 1985 - Komi-permyatsko-russkii slovar' [Komi-Permian-Russian dictionary]. Comp. by R. M. Batalova, A. S. Krivoshchekova-Gantman. Moscow: Russkii yazyk Publ., 1985. 624 p. In Komi-Permyak, Russian.

KESK - Lytkin V. I., Gulyaev E. S. Kratkii etimologicheskii slovar' komi yazyka [A concise etymological dictionary of the Komi language]. Syktyvkar, Komi Book Publ. House. 1999. 430 p. In Russian.

MRTK-I - Materialy I respublikanskogo toponimicheskogo konkursa. Rukopisnyj fond Udmurtskogo instituta istorii, yazyka i literatury Udmurtskogo Federal'nogo issledovatel'skogo centra UrO RAN [Materials of the I Republican toponymic competition. Manuscript Fund of the Udmurt Institute of History, Language and Literature of the Udmurt Federal Research Center of the Ural Branch of the Russian Academy of Sciences]. Op. 2-N, d. № 255. In Udmurt, Russian.

Nasibullin R. Sh. Kommentarij k karte «Ulicza» [Comment on the «Street» map]. Dialektologicheskij atlas udmurtskogo yazyka: Karty i kommentarii [Dialectological atlas of the Udmurt language: Maps and comments]. Izhevsk: NITs Regulyarnaya i khaoticheskaya dinamika, 2009. Iss. I. P. 188-189. In Udmurt, Russian.

Ozhegov S. I. Slovar' russkogo yazy'ka [The Dictionary of the Russian language]. Moscow: Russkii Yazyk Publ., 1989. 924 p. In Russian.

Podol'skaya N. V. Slovar' russkoi onomasticheskoi terminologii [The Dictionary of Russian onomastic terminology]. Moscow: Nauka Publ., 1988. 192 p. In Russian.

RBS - Russko-bashkirskii slvar' [Russian-Bashkir dictionary]. Ed. by Z. G. Uraksin. Ufa, 2005. URL: http://mfbl2.ru/mfbl/rusbash (accessed 12 August 2020). In Russian, Bashkir.

RKS 2003 - Beznosikova L. M., Zaboeva N. K., Kosnyreva R. I. Russko-komi slovar' [Russian-Komi dictionary]. Syktyvkar: Komi Book Publ. House, 2003. 1104 p. In Russian, Komi.

Sadikov R. R. Kissa gurt kotyrys' intynim"yos [Toponyms near the Kissa village]. Vordskem kyl [Native word]. Izhevsk, 2004. № 7 (109). Pp. 78-84. In Udmurt.

Samarova M. A. Naimenovaniya topoob"ektov Verhnej Chepcy [Names of topoobjects of the Upper Cheptsa]. Izhevsk: Udmurtskii universitet Publ., 2010. 246 p. In Russian.

SARRAS - Myuller V. K. Sovremennyi anglo-russkii i russko-angliiskii slovar' [Modern English-Russian and Russian-English dictionary]. Moscow: DOM. XXI vek: RIPOL klassik Publ., 2010. 541 p.

Sattar-Mulille G. Isemeß̧ matur, kemnər kujgan? [What is your name?] Kazan: Akademiya poznaniya Publ., 2006. 544 p. In Tatar.

SRYa - Slovar' russkogo yazyka: v 4 tomakh [The Dictionary of the Russian language: in 4 volumes]. Ed. A. P. Evgenieva. Moscow: Russkii yazyk Publ., 1981-1984. In Russian.

STSRYa - Sovremennyi tolkovyi slovar' russkogo yazyka [The modern explanatory dictionary of the Russian language]. Ch. ed. S. A. Kuznetszov. Moscow: Riderz Dajdzhest Publ., 2004. 960 p. In Russian.

TRS 2007 - Tatarsko-russkii slovar': v 2 tomakh [Tatar-Russian dictionary: in 2 volumes]. Kazan: Magarif Publ. 2007. Vol. 2 (M - Ya). 726 p. In Tatar, Russian. 
URS 2008 - Udmurtsko-russkii slovar' [Udmurt-Russian Dictionary]. Comp. T. R. Dushenkova, A. Egorov, L. M. Ivshin and others; ed. L. E. Kirillova. Izhevsk, Udmurtian Institute of History, Language and Literature, Ural Branch of the Russian Academy of Sciences Publ., 2008. 925 p. In Udmurt, Russian.

Tsygankin D. V. Pamyat', zapechatlennaya v slove: Slovar' geograficheskikh nazvanii Respubliki Mordoviya [Memory imprinted in the word: The Dictionary of Geographical Names of the Republic of Mordovia]. Saransk: Krasnyi Oktyabr' Publ., 2005. 432 p. In Russian.

ChRS - Chuvashsko-russkii slovar' [Chuvash-Russian dictionary]. Ed. Skvorczov. Moscow: Russkii yazyk Publ., 1982. 712 p. In Chuvash, Russian.

Shestakov V. Glazovskii uezd [Glazov county]. Vestnik Imperatorskogo Russkogo geograficheskogo obshhestva [Bulletin of the Imperial Russian Geographical Society]. Sankt-Peterburg. 1859. № 7. P. $73-111$. In Russian.

Shklyaev G. K. Iz istorii formirovaniya sel'skogo rasseleniya i razvitiya poselenii na territorii Udmurtii (XIX - nach. XX vv.) [From the history of the formation of rural settlement and the development of settlements on the territory of Udmurtia (XIX - beginning of the XX centuries)]. Sel'skie poseleniya Udmurtii $v X I X-X X v v .:$ Sbornik statei [Rural settlements of Udmurtia in the XIX-XX centuries: A collection of articles]. Izhevsk: Research Institute under the Council of Ministers of the Udmurt ASSR. 1981. P. 3-44. In Russian.

OMK 1975 - Gáldi L. Orosz-magyar kéziszótár (= Russko-vengerskii slovar') [Russian-Hungarian dictionary]. Budapest, Akadémiai Kiadó Publ., 1975. 1120 p. In Russian, Hungarian.

EVS 1974 - I. Tamm. Eesti-vene sõnaraamat (= Эстонско-русский словарь) [Estonian-Russian dictionary]. Tallinn, Valgus Publ., 1974, 546 p.

SVS - Suomalais-venäläinen sanakirja (= Финско-русский словарь) [Finnish-Russian Dictionary]. Comp. by I. Vakhros and A. Shcherbakov. Edition third. Porvoo - Helsinki - Yuva, Werner Söderström Osakeyhtiö Publ., 1995. 816 p.

UEW - Rédei K. Uralisches etymologisches Wörterbuch [Uralic etymological dictionary]. Budapest, Akadémiai Kiadó Publ., 1988. Vol. 7. Pp. 733-906. In German.

Received 29.10.2021

Kirillova Lyudmila Jevgenyevna, Candidate of Science (Philology), Senior Research Associate, Udmurt institute of History, Language and Literature UdmFRC UB RAS, 4, Lomonosov st., Izhevsk, 426004, Russian Federation, e-mail: kirlud@rambler.ru 
Приложение

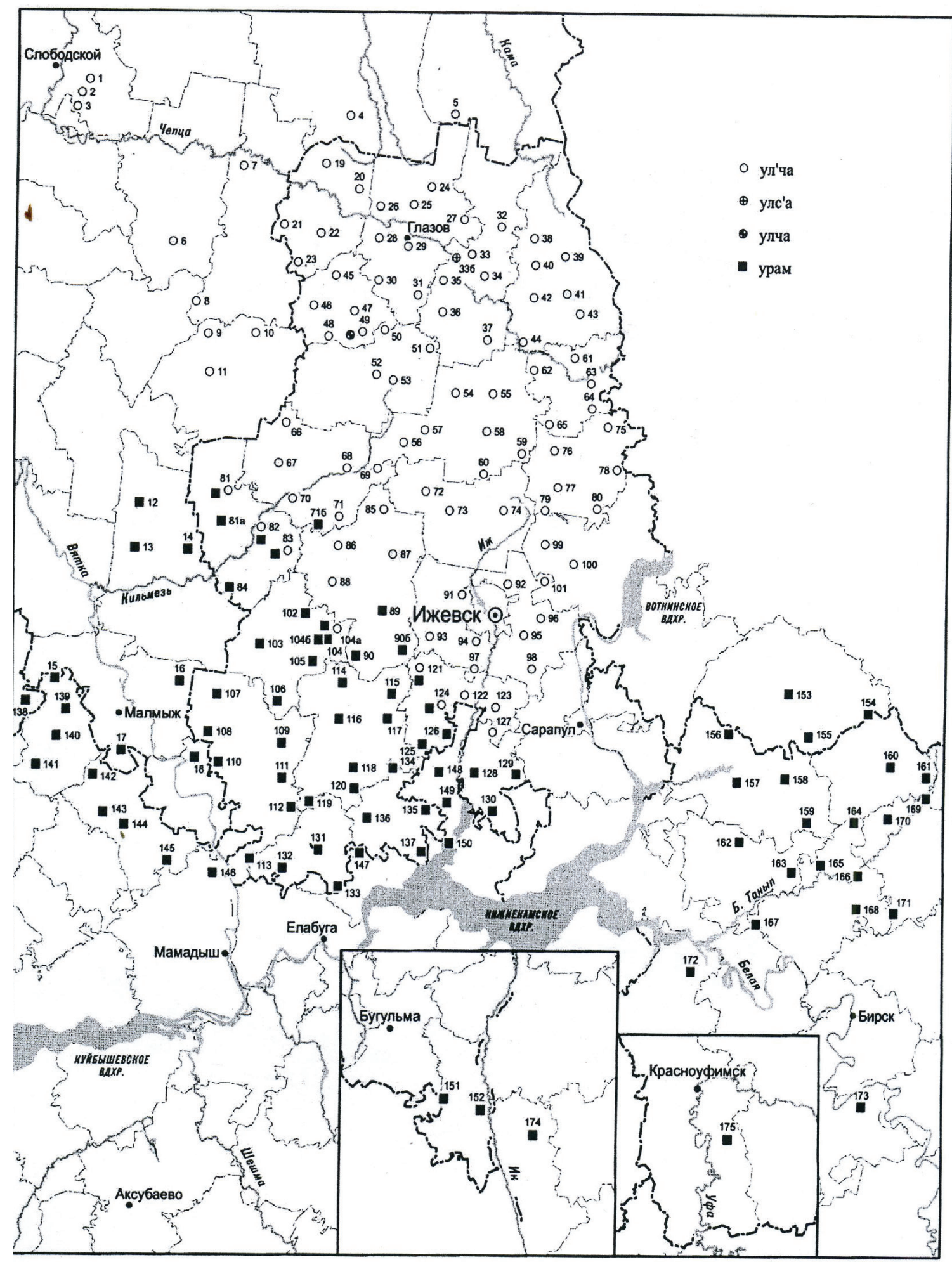

Карта. Распространение слов ул'ча и урам в диалектах и говорах удмуртского языка 